\title{
Article \\ Chemical Profile, Antioxidant Properties and Antimicrobial Activities of Malaysian Heterotrigona itama Bee Bread
}

\author{
Joseph Bagi Suleiman ${ }^{1,2} \mathbb{D}$, Mahaneem Mohamed ${ }^{1,3} * \mathbb{D}$, Ainul Bahiyah Abu Bakar ${ }^{1}$, Victor Udo Nna ${ }^{4}$, \\ Zaida Zakaria ${ }^{1}\left(\mathbb{D}\right.$, Zaidatul Akmal Othman ${ }^{1,5} \mathbb{D}$ and Abdulqudus Bola Aroyehun ${ }^{6,7}$
}

1 Department of Physiology, School of Medical Sciences, Universiti Sains Malaysia, Kubang Kerian 16150, Kelantan, Malaysia; bagisuleiman@yahoo.com (J.B.S.); ainul@usm.my (A.B.A.B.); zaida_zakaria@ymail.com (Z.Z.); drzaida87@gmail.com (Z.A.O.)

2 Department of Science Laboratory Technology, Akanu Ibiam Federal Polytechnic, Unwana P.M.B. 1007, Ebonyi State, Nigeria

3 Unit of Integrative Medicine, School of Medical Sciences, Universiti Sains Malaysia, Kubang Kerian 16150, Kelantan, Malaysia

4 Department of Physiology, Faculty of Basic Medical Sciences, College of Medical Sciences, University of Calabar, Calabar P.M.B. 1115, Cross River State, Nigeria; victor2nna@gmail.com

5 Unit of Physiology, Faculty of Medicine, Universiti Sultan Zainal Abidin, Kuala Terengganu 20400, Terengganu, Malaysia

6 Nutrition and Dietetics Program, School of Health Sciences, Universiti Sains Malaysia, Kubang Kerian 16150, Kelantan, Malaysia; bqaroyehun@student.usm.my

7 Clinical Nutrition, The Rowett Institute of Nutrition and Health, University of Aberdeen, Scotland AB24 3FX, UK

check for updates

Citation: Suleiman, J.B.; Mohamed, M.; Abu Bakar, A.B.; Nna, V.U.; Zakaria, Z.; Othman, Z.A.; Aroyehun, A.B. Chemical Profile, Antioxidant Properties and Antimicrobial Activities of Malaysian Heterotrigona itama Bee Bread. Molecules 2021, 26, 4943. https://doi.org/10.3390/ molecules26164943

Academic Editor: Silvie Rimpelova

Received: 13 July 2021

Accepted: 11 August 2021

Published: 15 August 2021

Publisher's Note: MDPI stays neutral with regard to jurisdictional claims in published maps and institutional affiliations.

Copyright: (c) 2021 by the authors. Licensee MDPI, Basel, Switzerland. This article is an open access article distributed under the terms and conditions of the Creative Commons Attribution (CC BY) license (https:// creativecommons.org/licenses/by/ $4.0 /)$.
* Correspondence: mahaneem@usm.my

\begin{abstract}
The aim of the study was to determine the chemical profile, antioxidant properties and antimicrobial activities of Heterotrigona itama bee bread from Malaysia. The $\mathrm{pH}$, presence of phytochemicals, antioxidant properties, total phenolic content (TPC) and total flavonoid content (TFC), as well as antimicrobial activities, were assessed. Results revealed a decrease in the $\mathrm{pH}$ of bee bread water extract (BBW) relative to bee bread ethanolic extract (BBE) and bee bread hot water extract (BBH). Further, alkaloids, flavonoids, phenols, tannins, saponins, terpenoids, resins, glycosides and xanthoproteins were detected in BBW, BBH and BBE. Also, significant decreases in TPC, TFC, DPPH activity and FRAP were detected in BBW relative to $\mathrm{BBH}$ and BBE. We detected phenolic acids such as gallic acid, caffeic acid, trans-ferulic acid, trans 3-hydroxycinnamic acid and 2-hydroxycinnamic acid, and flavonoids such as quercetin, kaempferol, apigenin and mangiferin in BBE using highperformance liquid chromatography analysis. The strongest antimicrobial activity was observed in Klebsilla pneumonia $\left(\mathrm{MIC}_{50} 1.914 \mu \mathrm{g} / \mathrm{mL}\right.$ ), followed by E. coli $\left(\mathrm{MIC}_{50} 1.923 \mu \mathrm{g} / \mathrm{mL}\right)$, Shigella $\left(\mathrm{MIC}_{50}\right.$ $1.813 \mu \mathrm{g} / \mathrm{mL}$ ) and Salmonella typhi (MIC ${ }_{50} 1.617 \mu \mathrm{g} / \mathrm{mL}$ ). Bee bread samples possess antioxidant and antimicrobial properties. Bee bread contains phenolic acids and flavonoids, and could be beneficial in the management and treatment of metabolic diseases.
\end{abstract}

Keywords: Heterotrigona itama bee bread; polyphenols; microbial activities

\section{Introduction}

Bee bread comprises of pellets of bee pollen packed by foraging bees and conveyed to the bee hive on their hind legs in a pollen bag [1]. It is made from pollen assembled by bee and mixed with honey and salivary enzymes. Bee bread contains a high amount of lactic acid relative to bee pollen and also contains protein, antioxidant and phenolic compounds [2].

The scavenging worker bees are responsible for the collection of pollen pellets from flowers back to the hives, which are then assembled by younger bees into compartments of the brood comb [3]. Furthermore, honey is placed on the pollen to avoid decay, after 
which microorganisms like bacteria/yeast act upon it to produce bee bread in a process referred to as lactic acid fermentation. Thereafter, it is eaten by adult bees and also used as a source of food to feed larvae [4]. Generally, bees obtain protein from pollen which are separated from nectar. Bee bread is composed of $20 \%$ protein, $24-35 \%$ carbohydrates, $3 \%$ lipids, 3\% minerals and vitamins (B1, B2, C, E, K, biotin, folic acid and nicotinic acid), pantothenic acid, polyphenols (phenolic acid and flavonoids), sterols, enzymes (amylase, saccharase and phosphatases) and carotenoids [5,6].

It has been suggested that bee bread possesses a large amount of protein and amino acid because bee pollen also possesses a high amount of these nutrients [7]. It has also been found that the amount of protein in bee bread depends largely on the type of flower, pollen grains and region where they are located. Considerable amounts of enzymes (phosphatase, glucose-oxidase and amylase) and amino acids (glutamic acid, proline, aspartic acid, arginine, histidine, valine, leucine, isoleucine, methionine, lysine, tryptophan, threonine, phenylalanine, cysteine, alanine, tyrosine, glycine and serine) are present in bee bread [8].

The hydrolysis of monosaccharides during lactic acid fermentation of the pollen produces $0.12 \%$ sucrose, $3.37 \%$ maltose, $42.59 \%$ glucose and $57.51 \%$ fructose, which are present in bee bread, and $1.82 \%$ disaccharides (trehalose, turanoe and isomaltose) are also found as well [9]. The process of fermentation where Lactobacillus sp. uses carbohydrates as a source of oxygen to produce lactic acid up to a concentration of $3.2 \%$ occurs in the hives [8].

Kaplan et al. [10] reported that eight varieties of Turkish bee bread contained 1.9$2.54 \%$ ash, $14.8-24.3 \%$ protein, $5.9-11.5 \%$ fat, and $11.4-15.9 \%$ moisture, as well as fatty acids. Apart from that, bee bread contains magnesium, calcium, phosphorus, sodium, iron, potassium, zinc, manganese, copper, silicon and aluminium [11]; vitamins (folic acid, niacin, vitamin B6, vitamin C, pantothenic acid), and flavonoids (pinocembrin) [12].

Studies on varieties of Morroccan bee bread to prove its resistance to antibiotics revealed strong antimicrobial activities on the bacterial strains [13]. On the other hand, a research study carried out by Tichy and Novak [14] revealed that bee bread hydrophobic compounds had antibacterial activity against Viridans streptococci. Bee bread was also found to possess antibacterial activity against Staphlococcus aureus and Staphlococcus epidermidis [15].

The antifungal and antioxidant activities of bee bread and their relationship with phenolic compounds have been reported [13]. Similarly, studies have also revealed antiinflammatory activities of bee bread, making it one of the strongest anti-inflammatory natural products [16-18]. Furthermore, antitumor effects of bee bread have been reported on ovary, hepatoma, prostate, bladder, melanoma and renal cancer cells, with varrying mechanisms of action depending on the tumor type [19]. Immunoactivating activity of bee bread has been reported in different studies $[13,20]$. The aim of this present study was to assess and compare the phytochemical screening, antioxidant properties, high-performance liquid chromatography and antimicrobial activities of extracts of Malaysian Heterotrigona itama bee bread.

\section{Results}

\section{1. $p H$ of Heterotrigona itama Bee Bread}

There was a significant decrease $(p<0.05)$ in the $\mathrm{pH}$ of Heterotrigona itama bee bread water extract (BBW) relative to Heterotrigona itama bee bread ethanolic extract (BBE). The $\mathrm{pH}$ did not vary significantly between BBE and Heterotrigona itama bee bread hot water extract (BBH) (Figure 1). 


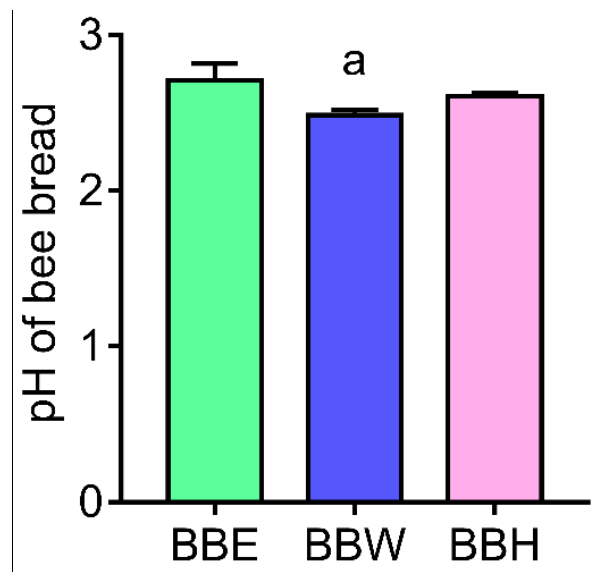

Figure 1. $\mathrm{pH}$ of bee bread. BBE: bee bread ethanol extract, $\mathrm{BBW}$ : bee bread water extract. $\mathrm{BBH}$ : bee bread hot water extract, ${ }^{a} p<0.05$ versus BBE.

\subsection{Phytochemical Screening Analysis of Heterotrigona itama Bee Bread}

Qualitative data of phytochemicals revealed an abundance of alkaloids, flavonoids, phenols, terpenoids, resins and glycosides in BBE compared to BBW and BBH, while similar results were obtained in all three samples for tannins, saponins and xanthoproteins. In BBE, the most abundant phytochemicals were terpenoids and flavonoids (Table 1).

Table 1. Phytochemical screening analysis of BBE, BBW and BBH extract.

\begin{tabular}{cccc}
\hline Compound & BBE & BBW & BBH \\
\hline Phenols & ++ & + & + \\
Glycosides & ++ & + & + \\
Alkaloids & ++ & + & + \\
Xanthoproteins & + & + & + \\
Terpenoids & +++ & + & ++ \\
Tannins & + & + & ++ \\
Resins & ++ & ++ & ++ \\
Saponins & ++ & + & ++ \\
Flavonoids & +++ & + & ++ \\
\hline
\end{tabular}

BBE: bee bread ethanol extract, BBW: bee bread water extract: BBH: bee bread hot water extract, Positive sign (+) represents the intensity of colour change. The higher the concentration the more the positive sign.

\subsection{Analysis of In Vitro Antioxidant Assessment of Heterotrigona itama Bee Bread}

The in vitro antioxidant assessments were carried out on BBE, BBW and BBH using 1,1-diphenyl-2-picrylhydrazyl (DPPH) radical, hydrogen peroxide $\left(\mathrm{H}_{2} \mathrm{O}_{2}\right)$ scavenging, total phenolic and flavonoid contents, as well as ferric ion reducing antioxidant power (FRAP) assays.

\subsubsection{DPPH Radical and $\mathrm{H}_{2} \mathrm{O}_{2}$ Scavenging Activities of Heterotrigona itama Bee Bread}

The DPPH radical scavenging activity of BBE was significantly higher than BBW and $\mathrm{BBH}$. However, $\mathrm{BBH}$ was significantly higher than BBW (Figure 2a,b). The half-maximal inhibitory concentration $\left(\mathrm{IC}_{50}\right)$ of $\mathrm{BBE}$ and $\mathrm{BBW}$ were $2.139 \mu \mathrm{g} / \mathrm{mL}$ and $2.694 \mu \mathrm{g} / \mathrm{mL}$, respectively. Interestingly, the $\mathrm{IC}_{50}$ for $\mathrm{BBH}$ was slightly lower $(1.745 \mu \mathrm{g} / \mathrm{mL})$ than $\mathrm{BBE}$ and BBW (Figure 2a,b). 


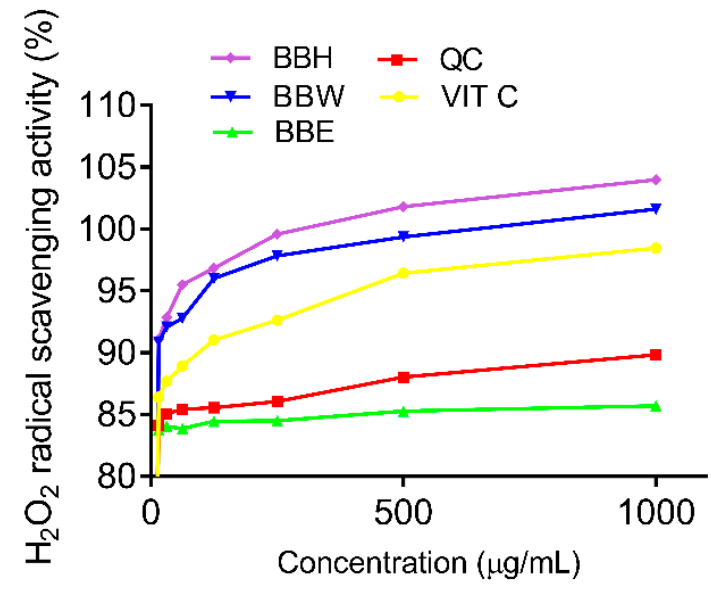

(a)

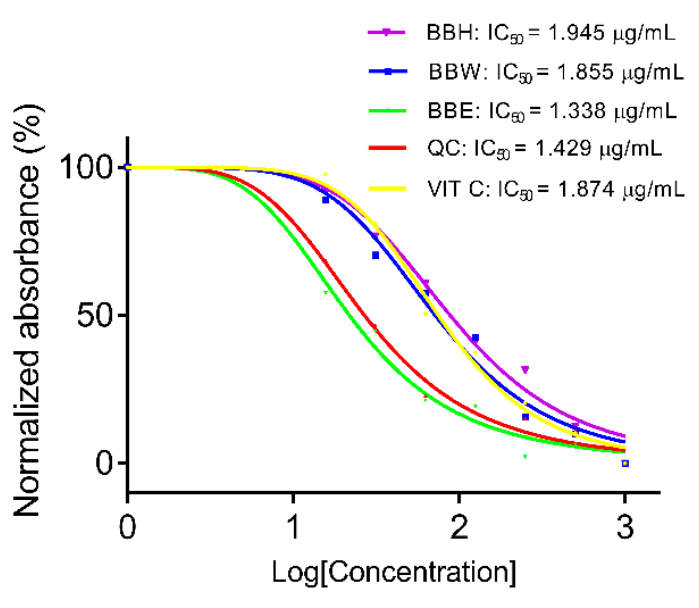

(b)

Figure 2. $\mathrm{H}_{2} \mathrm{O}_{2}$ scavenging activity (a) and normalized absorbance of $\mathrm{H}_{2} \mathrm{O}_{2}(\mathbf{b}) \cdot \mathrm{H}_{2} \mathrm{O}_{2}$ : hydrogen peroxide, $\mathrm{BBE}$ : bee bread ethanol extract $\left(\mathrm{IC}_{50}: 1.338 \mu \mathrm{g} / \mathrm{mL}\right), \mathrm{BBW}$ : bee bread water extract $\left(\mathrm{IC}_{50}: 1.855 \mu \mathrm{g} / \mathrm{mL}\right), \mathrm{BBH}$ : bee bread hot water extract $\left(\mathrm{IC}_{50}: 1.945 \mu \mathrm{g} / \mathrm{mL}\right)$, VITC: Vitamin C (IC $\left.50: 1.874 \mu \mathrm{g} / \mathrm{mL}\right)$, QC: quercetin $\left(\mathrm{IC}_{50}: 1.429 \mu \mathrm{g} / \mathrm{mL}\right)$.

Similarly, the scavenging activity of $\mathrm{H}_{2} \mathrm{O}_{2}$ showed that $\mathrm{BBW}$ and $\mathrm{BBH}$ were significantly lower relative to $\mathrm{BBE}$ (Table 2). While the $\mathrm{IC}_{50}$ of $\mathrm{BBW}$ and $\mathrm{BBH}$ were $1.855 \mathrm{\mu g} / \mathrm{mL}$ and $1.945 \mu \mathrm{g} / \mathrm{mL}$, respectively, the $\mathrm{IC}_{50}$ for BBE was lower $(1.338 \mu \mathrm{g} / \mathrm{mL}$ ) (Figure $3 \mathrm{a}, \mathrm{b})$.

Table 2. In vitro antioxidant activities of BBE, BBW and BBH extracts.

\begin{tabular}{|c|c|c|c|}
\hline Parameter & BBE & BBW & BBH \\
\hline DPPH radical scavenging activity (\%) & $85.79 \pm 0.40$ & $7.62 \pm 0.13^{\mathrm{a}}$ & $8.47 \pm 0.01^{\mathrm{a}, \mathrm{b}}$ \\
\hline Hydrogen peroxide scavenging activity (\%) & $90.53 \pm 2.14$ & $74.21 \pm 1.61$ & $69.61 \pm 0.98^{\mathrm{a}, \mathrm{b}}$ \\
\hline FRAP $\left(\mu \mathrm{mol} \mathrm{Fe}{ }^{2+} \mathrm{Eq} / \mathrm{L}\right)$ & $106.7 \pm 1.47$ & $68.49 \pm 0.94^{\mathrm{a}}$ & $48.59 \pm 1.95^{\mathrm{a}, \mathrm{b}}$ \\
\hline Total phenolic content (mg GAE $\mathrm{g}^{-1}$ ) & $17.44 \pm 0.93$ & $9.80 \pm 0.10^{\mathrm{a}}$ & $9.55 \pm 1.00^{\mathrm{a}}$ \\
\hline Total flavonoid content (mg QE $\left.\mathrm{g}^{-1}\right)$ & $21.34 \pm 0.83$ & $2.69 \pm 0.09^{\mathrm{a}}$ & $4.82 \pm 0.37^{\mathrm{a}, \mathrm{b}}$ \\
\hline
\end{tabular}

BBE: bee bread ethanol extract, BBW: bee bread water extract: BBH: bee bread hot water extract, DPPH: 1,1 diphenyl 2 picrylhydrazyl, FRAP: ferric ion reducing antioxidant power. Values are expressed in mean $\pm \mathrm{SD}, \mathrm{n}=3 .{ }^{\mathrm{a}} p<0.05$ versus BBE, ${ }^{\mathrm{b}} p<0.05$ versus BBW (one-way analysis of variance followed by Tukey's post hoc test).

\subsubsection{Total Phenolic and Flavonoid Contents of Heterotrigona itama Bee Bread}

The total phenolic and flavonoid contents were significantly higher in BBE relative to $\mathrm{BBW}$ and $\mathrm{BBH}$. However, the flavonoid content was significantly higher in $\mathrm{BBH}$ relative to BBW. BBE had the highest phenolic and flavonoid contents (Table 2).

\subsubsection{Ferric Ion-Reducing Antioxidant Power (FRAP) of Heterotrigona itama Bee Bread}

FRAP activity was significantly lower in BBW and BBH relative to BBE. The lowest FRAP activity was detected in $\mathrm{BBH}$, and was significantly lower relative to BBW. On the other hand, BBE had the highest FRAP activity (Table 2).

\subsubsection{Phenolic Compounds Analysis of BBE Using High-Performance Liquid Chromatography (HPLC)}

Nine phenolic compounds were identified in BBE using HPLC analysis. These include phenolic acids such as gallic acid, caffeic acid, trans-ferulic acid, trans 3-hydroxycinnamic acid and 2-hydroxycinnamic acid, and flavonoids such as quercetin, kaempferol, apigenin and mangiferin. The result in the chromatogram revealed the retention time for compounds from the least to the highest retention time: gallic acid $<$ caffeic acid $<$ mangiferin $<$ trans-ferulic acid $<$ trans 3-hydroxycinnam acid $<2$-hydroxycinnam acid $<$ quercetin $<$ 
kaempferol < apigenin. This is in agreement with standards of gallic acid $(6.0)<$ caffeic acid $(12.5)<$ mangiferin $(13.1)<$ trans-ferulic acid $(14.6)<$ trans 3-hydroxycinnam acid (15.9) < 2-hydroxycinnam acid (15.6) < quercetin (17.5) < kaempferol (18.7) < apigenin (19.1). On the other hand, area for the compounds from least to highest were trans ferulic acid $<$ caffeic acid $<$ gallic acid $<$ mangiferin $<2$-hydroxycinnam acid $<$ kaempferol $<$ apigenin $<$ quercetin $<$ trans 3-hydroxycinnam acid (Figure 4).

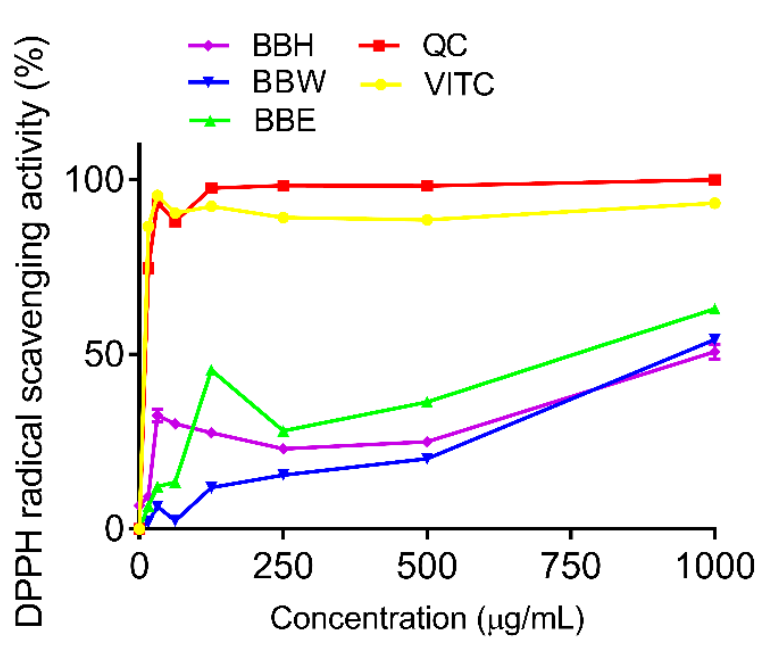

(a)

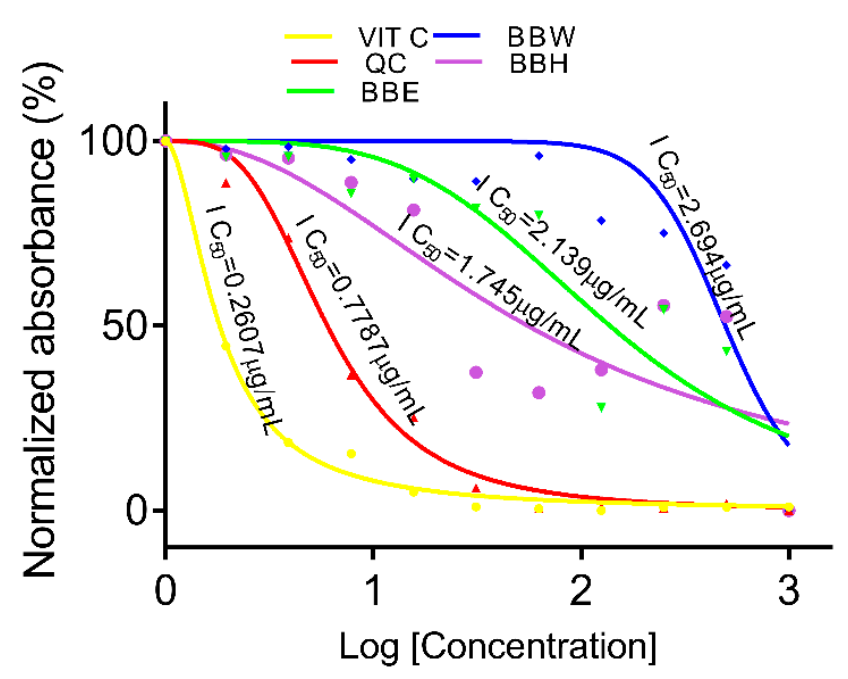

(b)

Figure 3. DPPH radical scavenging activity (a) and normalized absorbance of DPPH activity (b). DPPH: 1,1 diphenyl 2 picrylhydrazyl, BBE: bee bread ethanol extract $\left(\mathrm{IC}_{50}: 2.139 \mu \mathrm{g} / \mathrm{mL}\right), \mathrm{BBW}$ : bee bread water extract $\left(\mathrm{IC}_{50}: 2.694 \mu \mathrm{g} / \mathrm{mL}\right), \mathrm{BBH}$ : bee bread hot water extract ( $\left.\mathrm{IC}_{50}: 1.745 \mu \mathrm{g} / \mathrm{mL}\right)$, VITC: Vitamin C ( $\left.\mathrm{IC}_{50}: 0.2607 \mu \mathrm{g} / \mathrm{mL}\right)$, QC: quercetin $\left(\mathrm{IC}_{50}: 0.7787 \mu \mathrm{g} / \mathrm{mL}\right)$.

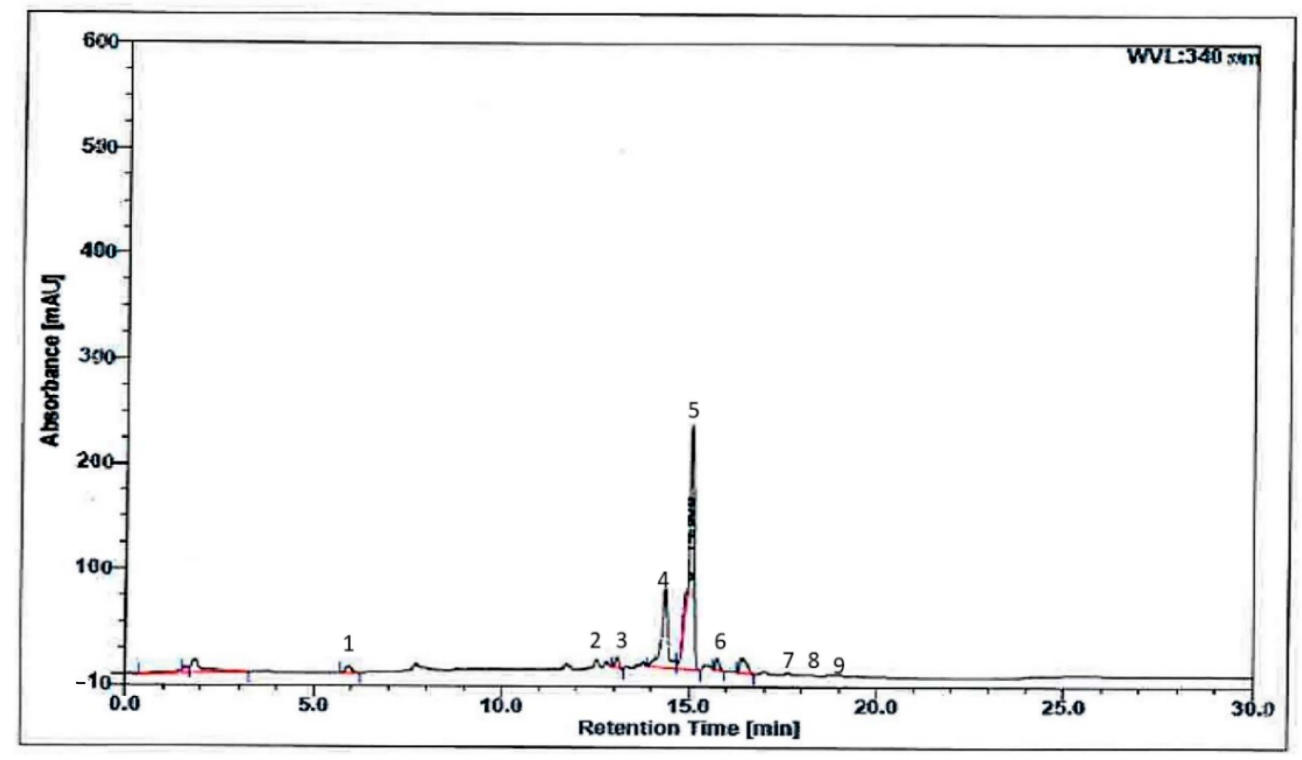

Figure 4. High-performance liquid chromatography analysis of BBE at $340 \mathrm{~nm}$. Peak 1: gallic acid, peak 2: caffeic acid, peak 3: mangiferin, peak 4: trans-ferulic acid, peak 5: trans 3-hydroxycinnam acid, peak 6: 2-hydroxycinnam acid, peak 7: quercetin, 8: kaempferol, peak 9: apigenin. 


\subsection{Antimicrobial Activities of Heterotrigona itama Bee Bread}

For this assay, BBE was used since it appeared to have the best antioxidant activity. The absorbance of various concentrations of Klebsilla pneumonia, E. coli, Shigella and Salmonella typhi and the positive controls (tetracycline, amoxycillin and Erythromycin) (Figure 5a-d) were normalized and used to obtain $\mathrm{MIC}_{50}$ values for antimicrobial activity. The antimicrobial activity of BBE was strongest in Shigella $\left(\mathrm{MIC}_{50}: 1.617 \mu \mathrm{g} / \mathrm{mL}\right.$ ), followed by Salmonella typhi $\left(\mathrm{MIC}_{50}: 1.813 \mu \mathrm{g} / \mathrm{mL}\right)$, E. coli $\left(\mathrm{MIC}_{50}: 1.914 \mu \mathrm{g} / \mathrm{mL}\right.$ ) and Klebsilla pneumonia $\left(\mathrm{MIC}_{50}\right.$ : $1.923 \mu \mathrm{g} / \mathrm{mL}$ ) (Figure 6a-f).

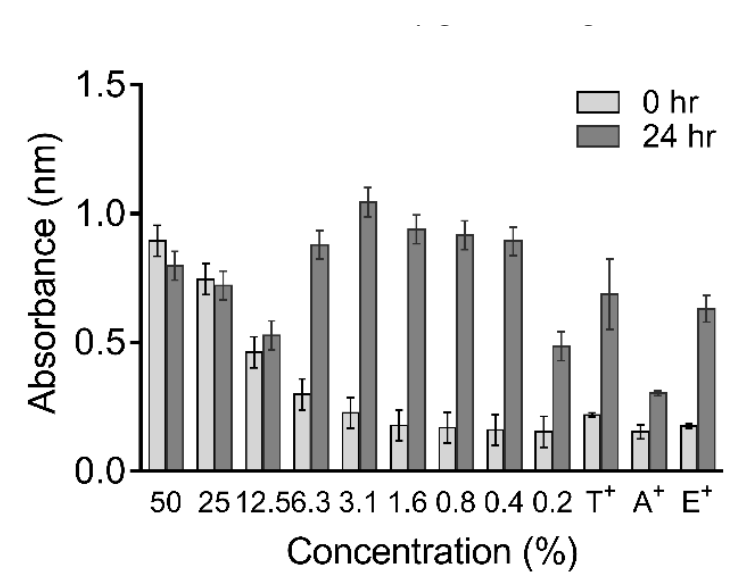

(a)

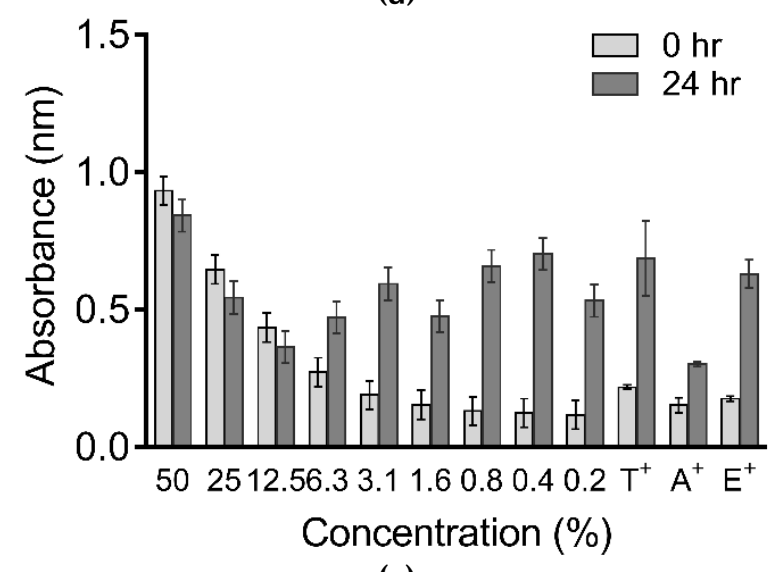

(c)

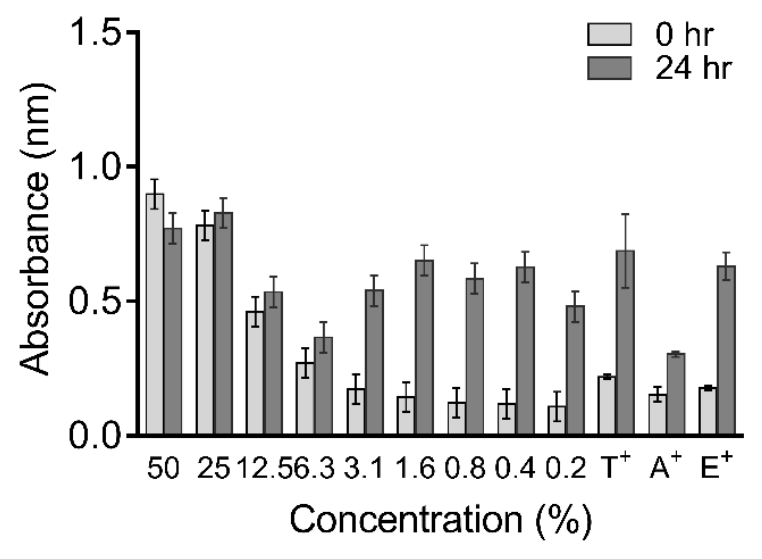

(b)

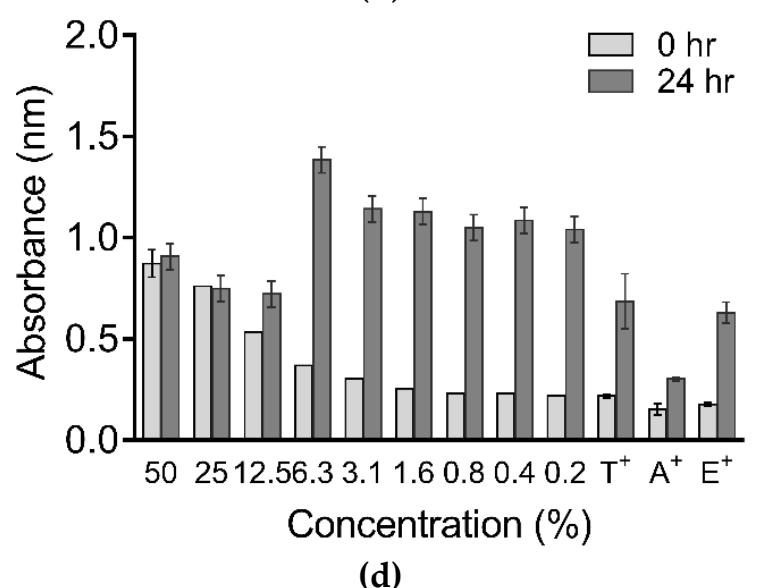

(d)

Figure 5. Absorbance of various concentrations of (a): E. coli, (b) S. typhi, (c): Shigella and (d) K. pneumonia. The absorbance was measured at $0 \mathrm{~h}$ and after $24 \mathrm{~h}$ of incubation. T: tetracycline, A: amoxycillin, and E: erythromycin were used as positive controls. 


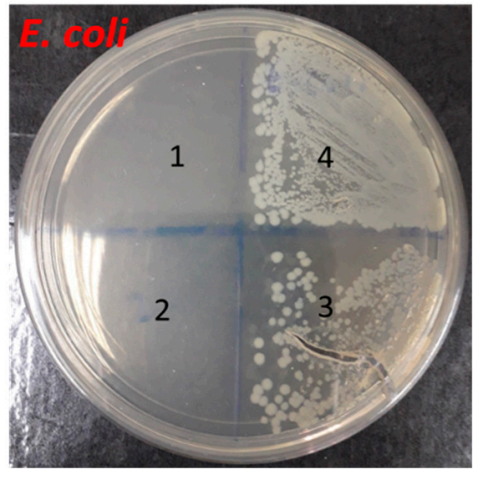

(a)

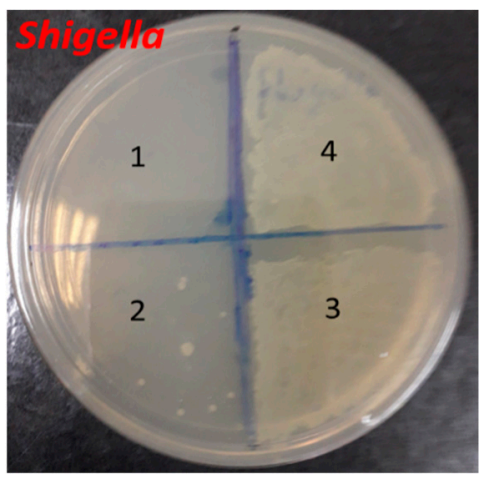

(c)

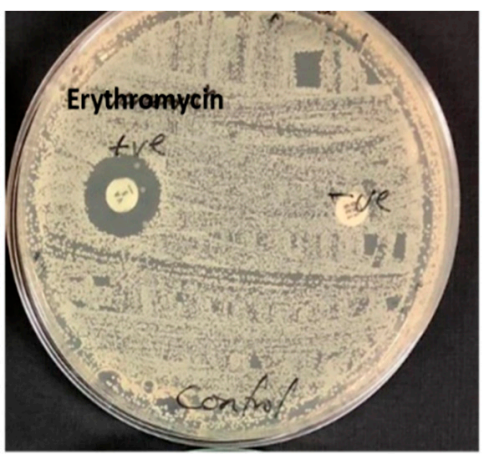

(e)

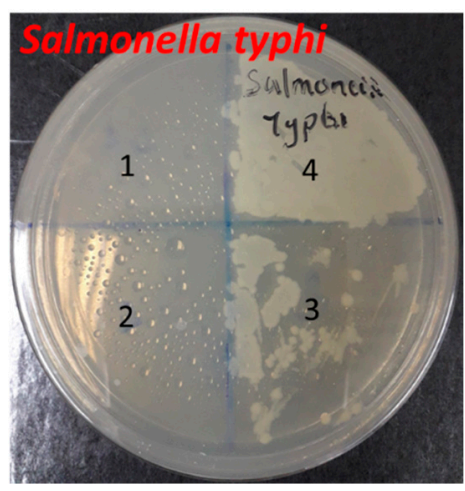

(b)

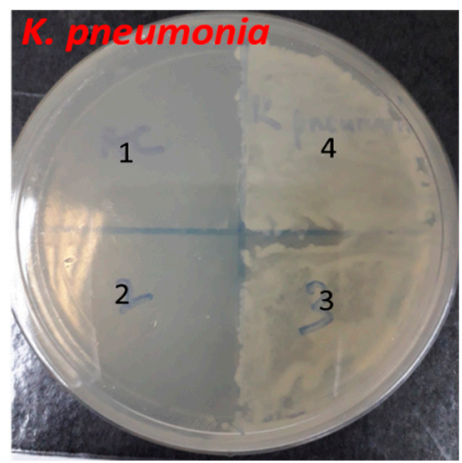

(d)

- Sh.: $\mathrm{IC}_{50}=1.617 \mu \mathrm{g} / \mathrm{mL}$

S. typ.: $\mathrm{IC}_{50}=1.813 \mu \mathrm{g} / \mathrm{mL}$

- E.C.: $: \mathrm{IC}_{50}=1.914 \mu \mathrm{g} / \mathrm{mL}$

- K. p.: $\mathrm{IC}_{50} 1.923 \mu \mathrm{g} / \mathrm{mL}$

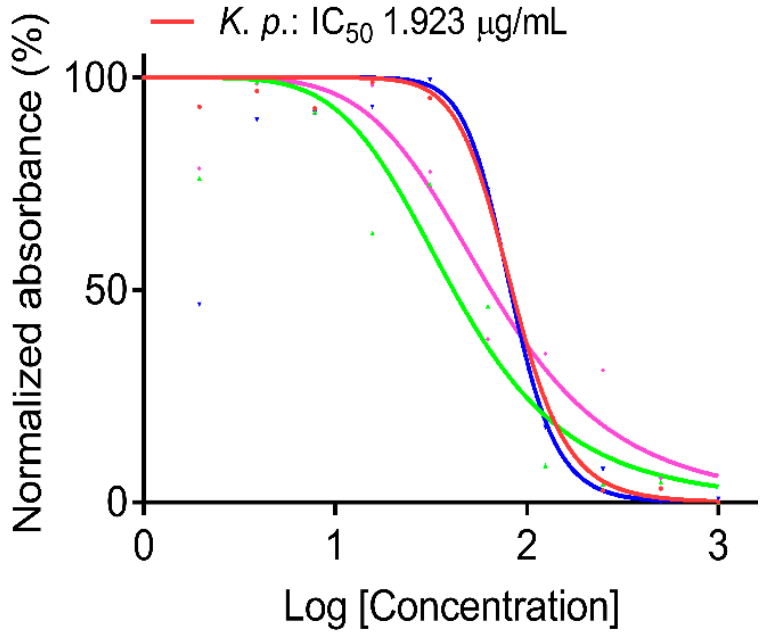

(f)

Figure 6. Antimicrobial activity of BBE in (a) E. coli, (b) Salmonella typhi, (c) Shigella, (d) K. pneumonia, (e) Erythromycin (control), (f) normalized absorbance of E. coli, Salmonella typhi, Shigella and K. pneumonia from which the $\mathrm{MIC}_{50}$ were calculated.

\section{Discussion}

Our previous studies assessed different samples of bee bread from three regions of Malaysia, namely: Selangor, Perak and Kelantan [21]. Results from the study revealed that bee bread from these regions possessed a variety of essential and non-essential amino acids, fats, carbohydrates, phenols and flavonoids, which gives it a high nutritive value. Further studies also revealed the presence of vitamins (B1, B2, A, E), calcium, iron, copper, sodium, potassium and cadmium; however, zinc and lead were not dictated in bee bread samples [22]. In the present study, we assessed the $\mathrm{pH}$ of bee bread, phytochemical 
screening, and in vitro antioxidant properties of three extracts of Heterotrigona itama bee bread (BBE, BBW and BBH). We also assessed the phenolic compounds analysis of BBE using HPLC, as well as the antimicrobial activity of the extract.

In this study, the $\mathrm{pH}$ of bee bread in the present study ( $\mathrm{pH}$ was lower than the range previously reported. This may be a result of the activities of lactic acid bacteria during the fermentation of bee pollen to bee bread. Previous studies revealed that the $\mathrm{pH}$ of bee bread ranges between 3.8 and 4.3 , which makes it differ from $\mathrm{pH}$ of bee pollen that ranges between 4.1 and 5.9. The low $\mathrm{pH}$ may be attributed to its high amount of lactic acid and carbohydrate, as well as low amount of proteins and fats as composition of bee bread may vary due to different sources and geographical locations [23,24].

There are several non-nutritive chemicals found in plants and natural products like honey products. These chemicals usually possess health-promoting properties. For many years, phytochemicals with unknown pharmacological activities have been studied as sources of phytotherapy. Research on phytochemicals has generally been considered as an effective approach in the discovery of new anti-infective agents from natural products. The samples of ethanolic extract of bee bread were used to determine preliminary phytochemical investigations which showed high concentrations of phenols, glycosides, alkaloids, resins, saponins, terpenoids, flavonoids, tannins and xanthoproteins. This is in line with studies carried out by Othman et al. [21], who reported that phytochemical compounds like xanthoproteins, flavonoids, phenols, saponins, tannins, terpenoids alkaloids, glycosides, resins, were found in bee bread ethanol extracts, while alkaloids were absent in bee bread aqueous extracts. The phytochemicals detected in this study are also similar to those reported previously [25], which have exhibited biological effects such as antimicrobial, antitumour and antihelmintic activities. Natural products usually possess large amounts of phenolic compounds, whose major role is antioxidant activities due to their redox properties, which makes them effective reducing agents, $\mathrm{H}^{+}$donors and $\mathrm{O}_{2}$ extinguishers. To increase the nutritional quality of food, phenolic compounds assist in the oxidative degradation of lipids, making them essential in the food industries.

The present study revealed the presence of phenolic and flavonoid contents in BBE, corroborating previous studies. For example, ethanolic and hexanic extracts of Heterotrigona itama bee bread were reported to show antioxidant properties [26]. Similarly, a study by Othman et al. [21] carried out on three samples of Malaysian bee bread from three different regions, Kelantan, Perak and Selangor, showed significantly higher antioxidant phenol property and higher phenolic and flavonoid content in ethanol extract of bee bread compared to aqueous extract of Heterotrigona itama bee bread. Phenolic-rich natural products have higher phenolic contents and exhibit stronger antioxidant capacity than natural products with less phenolic contents. Therefore, natural products with higher amounts of phenolic compounds, carbohydrates, protein, lipid and ash are considered good food materials with significant health benefits.

Heterotrigona itama bee bread is rich in amino acids, minerals, as well as polyphenols, carotenoids, flavonoids, phytosterols and other compounds [13]. In this present study, HPLC analysis of BBE revealed nine compounds such as gallic acid, caffeic acid, mangiferin, trans ferulic acid, trans 3-hydroxycinnamic acid, trans 2-hydroxycinnamic acid, quercetin, kaempferol and apigenin. The amount of apigenin was the highest, followed by kaempferol. This is consistent with previous studies of Baltrušaityte et al. [27], who reported that HPLC analysis of bee bread revealed high amounts of kaempferol, and a trace amount of pcoumaric acid, apigenin and chrysin, compared to honey. In addition to the compounds enumerated above, GC-MS results revealed trace quantities of flavonoids naringenin, quercetin, ferulic and caffeic acids in bee bread [28].

In a related study carried out on bee bread and bee pollen from Georgia, HPLC results identified the presence of quercetin, rutin and naringin [29]. A study carried out on six bee bread samples revealed thirty-two flavonoid derivatives, mainly kaempferol, quercetin, isorhamnetin, myricetin, and herbacetrin glycoside derivatives, with isrohamnetinO-hexosyl-O-rutinoside, isorhamnetin-O-pentosyl-hexoside and quercetin-3-O-rhamnoside 
relatively abundant [30]. Samples of bee bread from Romania and India showed high amounts of kaempferol-3-O-glycosides and hydrocinnamic acid derivatives analyzed with HighPerformance Liquid Chromatography with Diode Array Detection (HPLC/DAD) [31,32].

Previous study on samples of bee bread tested for antibacterial activities using Pseudomonas aeruginosa, Staphylococcus aureus, Bacillus cereus and Escherichia coli revealed that bee bread extracts were more sensitive to Gram-positive bacteria than Gram-negative bacteria [13]. In addition, antimicrobial activities of five samples of bee bread studied in Ukraine revealed the minimum inhibition concentration against the Gram-negative bacteria Salmonella enterica and E. coli as $6.40 \mu \mathrm{g} / \mathrm{mL}$ [33]. In Poland, alcoholic extracts of bee bread showed more antibacterial activity against Gram-positive bacteria when compared to water extract [34]. Ethanolic extract of bee bread inhibited the growth of Streptococcus; the bee bread showed inhibition against Gram-positive bacteria but not Gram-negative bacteria [27]. In our study, BBE inhibited the growth of microbes, with a higher activity against Shigella ( $\mathrm{MIC}_{50}: 1.617 \mu \mathrm{g} / \mathrm{mL}$ ) than Salmonella typhi $\left(\mathrm{MIC}_{50}: 1.813 \mu \mathrm{g} / \mathrm{mL}\right)$, E. coli $\left(\mathrm{MIC}_{50}: 1.914 \mu \mathrm{g} / \mathrm{mL}\right)$ and Klebsilla pneumonia $\left(\mathrm{MIC}_{50}: 1.923 \mu \mathrm{g} / \mathrm{mL}\right)$. This effect may be attributed to the rich polyphenol content of BBE, since polyphenols have significant antimicrobial properties.

\section{Materials and Methods}

\subsection{Collection and Preparation of Heterotrigona itama Bee Bread}

Bee bread samples were collected from a stingless bee farm (Mentari Technobee PLT), Kota Bharu, Kelantan, on the east coast region of Malaysia, Southeast Asia. During the dry season between the months of January and March, samples of Heterotrigona itama bee bread were collected and brought to the Laboratory of Department of Physiology, Universiti Sains Malaysia, Kelantan, Malaysia. They were weighed (initial weight) and then dried using a food dehydrator for $4 \mathrm{~h}$ at $35^{\circ} \mathrm{C}$ to remove moisture. The samples were weighed again after drying (final weight). The blender was used to blend the sample into fine powder and stored at $-20^{\circ} \mathrm{C}$ until further analysis.

\subsection{Preparation of Heterotrigona itama Bee Bread}

To $50 \mathrm{~g}$ of BBE, BBW and BBH powder, $500 \mathrm{~mL}$ of $70 \%$ ethanol, water and hot water were added, respectively, stirred and kept for $72 \mathrm{~h}$ at room temperature, after which the mixtures were stirred at $500 \mathrm{rpm}$ for $10 \mathrm{~min}$. Thereafter, they were centrifuged for 10 min at $4000 \mathrm{rpm}$ at $20^{\circ} \mathrm{C}$. Whatman filter paper No. 3 and No. 1 were used to filter the supernatant. The supernatants were freeze-dried and the final products (BBE, BBW and $\mathrm{BBH})$ were collected for analysis.

\section{3. $\mathrm{pH}$ of Heterotrigona itama Bee Bread}

Three hundred mg of each Heterotrigona itama bee bread sample were used to determine the $\mathrm{pH}$. Briefly, each bee bread sample was dissolved in a $1.5 \mathrm{~mL}$ centrifuge tube containing $300 \mu \mathrm{L}$ of distilled water or ethanol. A pH meter with an accuracy of +0.01 was used to measure the $\mathrm{pH}$ of the mixture.

\subsection{Phytochemical Screening of Heterotrigona itama Bee Bread}

Qualitative phytochemical screening was carried out on Heterotrigona itama bee bread extracts to determine the presence of alkaloids, flavonoids, phenols, tannins, saponins, terpenoids, resins, glycosides and xanthoproteins.

The presence of alkaloids was evaluated using Mayer's test, as previously described [35]. Briefly, $5 \mathrm{~mL}$ of $2 \%(v / v)$ of $\mathrm{HCl}$ were added to $50 \mathrm{mg}$ of extract, stirred and filtered. Thereafter, $1 \mathrm{~mL}$ of Mayer's reagent was added to the filtrate. A cream colour indicated the presence of alkaloids.

The presence of flavonoids was tested using a previously described method [36]. Next, $200 \mathrm{mg}$ of extract were placed in a test tube, followed by the addition of $10 \%$ ferric chloride. A brownish colour indicated the presence of flavonoid. In the test for phenols, few drops 
of $5 \%$ ferric chloride were added to a test tube containing $50 \mathrm{mg}$ of bee bread. A deep purple colour indicated phenols presence [35]. In the test for tannins, on the other hand, 2-3 drops of $0.1 \%$ ferric chloride were added to a test tube containing $50 \mathrm{mg}$ of extract and warmed for some minutes. The appearance of olive-green colour indicated the presence of tannins [37].

To test for the presence of saponin, three drops of olive oil were added to a test tube containing $500 \mathrm{mg}$ of extract. The persistent of froth and emulsion confirmed the presence of saponin [37]. To test for terpenoids, $2 \mathrm{~mL}$ of chloroform and $3 \mathrm{~mL}$ of $98 \%(v / v) \mathrm{H}_{2} \mathrm{SO}_{4}$ were pipetted into a test tube, followed by the addition of $500 \mathrm{mg}$ of extract. The appearance of a reddish-brown coloured layer indicated the presence of terpenoid [37].

To establish of presence of glycoside, a drop of $10 \%$ ferric chloride and $1 \mathrm{~mL}$ of concentrated sulphuric acid were added to a test tube containing $1 \mathrm{~mL}$ of glacial acetic acid. Thereafter, $100 \mathrm{mg}$ of extract were added along the side of the test tube. A reddish-brown colour confirmed the presence of glycoside [37]. To test for xanthoproteins, $200 \mathrm{mg}$ of extract were placed in a test tube, and 3 drops of $15 \%(v / v)$ nitric acid were added. A yellow colour indicated the presence of xanthoproteins [37].

\subsection{In Vitro Antioxidant Property of Heterotrigona itama Bee Bread}

In vitro antioxidant properties of the extracts were carried out to determine the DPPH radical scavenging activity, FRAP, $\mathrm{H}_{2} \mathrm{O}_{2}$ scavenging activity, total phenolic and flavonoid contents.

\subsubsection{DPPH Radical Scavenging Activity}

The method of Oršolić et al. [38] was used to determine DPPH radical scavenging activity of the extracts. Briefly, $1000 \mu \mathrm{L}$ of extract or standard prepared in methanol were added to DPPH methanol solution $(0.16 \mathrm{mM})$. The mixture was vortexed and kept in the dark for $30 \mathrm{~min}$ at room temperature, after which the absorbance was read at $512 \mathrm{~nm}$ wavelength using a spectrophotometer. Methanol $(1000 \mu \mathrm{L})$ was used as a control. The DPPH radical scavenging activity was performed in triplicates and the results were computed using the equation below:

DPPH radical scavenging activity $(\%)=[(\mathrm{ODc}-\mathrm{ODs}) / \mathrm{ODc}] \times 100$

Where: ODc $=$ absorbance of DPPH with methanol (control)

ODs $=$ absorbance of DPPH with extract or standard.

\subsubsection{Ferric Reducing Antioxidant Power}

The method as described by Benzie and Strain [39] was used to assess the FRAP activity of the extract. The method is based on the reduction of ferric tripyridyltrazine complex to ferrous tripyridyltrazine. Briefly, $200 \mu \mathrm{L}$ of bee bread extract were added to a test tube containing $1500 \mu \mathrm{L}$ of freshly prepared FRAP reagent made up of $10 \mathrm{mM}$ 2,4,6tripyridyl-S-triazine in $40 \mathrm{mM} \mathrm{HCl}, 20 \mathrm{mM} \mathrm{FeCl}_{3}$ solution and $0.3 \mathrm{M}$ acetate buffer in a ratio of 1:1:10, then the mixture was incubated for $4 \mathrm{~min}$ at $37^{\circ} \mathrm{C}$, after which the absorbance was read spectrophotometrically at $593 \mathrm{~nm}$ wavelength against distilled water blank. This assay was conducted in triplicates and results expressed in millimoles of ferrous per litre $\left(\mathrm{mmol} \mathrm{Fe}^{2+} \mathrm{Eq} \mathrm{L}^{-1}\right)$.

\subsubsection{Hydrogen Peroxide Scavenging Activity}

The $\mathrm{H}_{2} \mathrm{O}_{2}$ scavenging activity of bee bread extract was assessed according to a previously described method [40]. Concisely, to a test tube containing $0.6 \mathrm{~mL}$ of $\mathrm{H}_{2} \mathrm{O}_{2}(40 \mathrm{mM})$ solution in $0.1 \mathrm{M}$ phosphate buffer ( $\mathrm{pH} 7.4), 3.4 \mathrm{~mL}$ of the extract or standard prepared in $0.1 \mathrm{M}$ phosphate buffer ( $\mathrm{pH}$ 7.4) were added and mixed thoroughly. Phosphate buffer was used as blank. Thereafter, the mixture was incubated for $10 \mathrm{~min}$. Subsequently, the absorbance of the mixture was read spectrophotometrically at $230 \mathrm{~nm}$ wavelength. The $\mathrm{H}_{2} \mathrm{O}_{2}$ scavenging activity was performed in triplicates and results calculated and expressed in percentage using the equation: 
$\mathrm{H}_{2} \mathrm{O}_{2}$ scavenging activity $(\%)=[(\mathrm{ODc}-\mathrm{ODs}) / \mathrm{ODc}] \times 100$

Where: ODc $=$ absorbance of blank

ODs $=$ absorbance of sample

\subsubsection{Total Phenolic Content}

The method of Folin-Ciocalteu [41] was used to determine the total phenolic content in the extracts. Briefly, $200 \mu \mathrm{L}$ of each bee bread extract or standard were added into their respective test tubes containing $1 \mathrm{~mL}$ Folin-Ciocalteu phenol reagent in a ratio of 1:10, mixed and allowed to stand for $3 \mathrm{~min}$. Then, $1 \mathrm{~mL}$ of $10 \%$ sodium bicarbonate was added to the mixture and allowed to stand in the dark for $90 \mathrm{~min}$ after being made up to $10 \mathrm{~mL}$ with distilled water. The absorbance was read spectrophotometrically at $725 \mathrm{~nm}$ wavelength Total phenolic content was determined from a standard curve generated using gallic acid $(20,40,60,80$ and $100 \mu \mathrm{g} / \mathrm{mL})$. The assay was conducted in triplicates and results expressed in milligrams gallic acid equivalent per gram of extract $\left(\mathrm{mg} \mathrm{GAE}^{-1}\right)$.

\subsubsection{Total Flavonoid Content}

The method described by El Hariri et al. $[42,43]$ was used to determine the TFC in the extract. The reaction mixture contained bread extract $(1 \mathrm{~mL}), 4 \mathrm{~mL}$ of $70 \%$ ethanol, $300 \mu \mathrm{L}$ of sodium nitrite $(5 \% w / v), 300 \mu \mathrm{L}$ of aluminum chloride $(10 \% w / v), 2 \mathrm{~mL}$ of $1 \mathrm{M}$ sodium hydroxide and distilled water was added to make up the volume to $10 \mathrm{~mL}$. Absorbance was read at $510 \mathrm{~nm}$ wavelength after the mixture was properly vortexed. TFC was calculated from a standard curve generated using quercetin $(20,40,60,80$ and $100 \mu \mathrm{g} / \mathrm{mL})$. The TFC assay was conducted in triplicates and the results calculated were expressed in milligrams quercetin equivalent per gram of extract $\left(\mathrm{mg} \mathrm{QE} \mathrm{g}^{-1}\right)$.

\subsection{Determination of the Antimicrobial Activity of Heterotrigona itama Bee Bread 4.6.1. Minimum Inhibitory Concentration (MIC) Determination}

The microdilution method was used to determine the antimicrobial activity, employing Mueller-Hinton broth and Luria Bertania (LB) principles. BBE was dissolved in dimethyl sufoxide (DMSO, $10 \%$ of the final volume) and diluted with culture broth to a concentration of $2 \mathrm{mg} / \mathrm{mL}$. Furthermore, a concentration ranging from 2 to $0.0156 \mathrm{mg} / \mathrm{mL}$ was attained by adding culture broth through 1:2 serial dilution, out of which $100 \mu \mathrm{L}$ of the dilutions were pipetted into 96-well plates, as well as a sterility control and a growth control. Each test and growth control well were inoculated with $5 \mu \mathrm{L}$ of a bacterial suspension $(108 \mathrm{CFU} / \mathrm{mL}$ or $105 \mathrm{CFU} /$ well). All experiments were done in triplicate, after which the microdilution trays were incubated at $36^{\circ} \mathrm{C}$ for $18 \mathrm{~h}$. Bacterial growth was detected firstly by optical density (ELISA reader, CLX800-BioTek, Winooski, VT, USA) and by the addition of $20 \mu \mathrm{L}$ of an INT alcoholic solution $(0.5 \mathrm{mg} / \mathrm{mL})$ (Sigma, St. Louis, MO, USA). The trays were again incubated at $36^{\circ} \mathrm{C}$ for $30 \mathrm{~min}$, and in those wells where bacterial growth occurred, INT changed from yellow to purple. MIC values were defined as the lowest concentration of each natural product, which completely inhibited microbial growth. The results were expressed in $\mathrm{mg} / \mathrm{mL}$.

\subsubsection{Disc Diffusion Assay}

The antimicrobial activity of bee bread was performed by the disc diffusion method. Briefly, $0.5 \mathrm{McF}$ arland standards $(1 \times 108 \mathrm{CFU} / \mathrm{mL})$ was prepared overnight on cultures of bacteria (K. pnemonia, Shigella, E. coli and S. typhi) using peptone water; $10 \mu \mathrm{L}$ of each suspension was spread on the solid nutrient agar plates. A sterile disc of $6 \mathrm{~mm}$ was loaded with $10 \mu \mathrm{L}$ of BBE, antibiotics (ampicillin, tetracycline, amoxycillin) and DMSO as positive and negative controls, respectively. The sterile discs were then placed onto the surface of the inoculated nutrient agar plates. Thereafter, agar plates were incubated for $24 \mathrm{~h}$ at $37^{\circ} \mathrm{C}$. The diameter of the inhibition zones was measured in millimetres ( $\mathrm{mm}$ ). 


\subsubsection{Broth Dilution Method}

The minimum inhibitory concentration (MIC) of BBE was determined as described by Chen et al. [44]. The $10 \mathrm{~mL}$ sterile nutrient broth adjusted to appropriate turbidity was used to grow isolated colonies of the selected bacteria. Thereafter, it was cultured in various concentrations of BBE for $24 \mathrm{~h}$. The UV-Vis spectrophotometer (Shanghai Spectrum Instruments Co Ltd. Shanghai, China) was used to measure the initial turbidity of culture at $600 \mathrm{~nm}$ wavelength while the MIC of BBE was determined based on the cultures that were incubated at the same wavelength. MIC values were defined as the lowest concentration of each bee bread, which completely inhibited microbial growth. The experiment was performed in triplicates.

\subsection{High-Performance Liquid Chromatography (HPLC) Analysis of Heterotrigona itama Bee Bread}

Bee bread was screened for the presence of phenolic and flavoinoid compounds using HPLC technique. Briefly, the chromatography system with a flow rate of $1.0 \mathrm{~mL} / \mathrm{min}$, a Zorbax SB-C18 column $(3.5 \mu \mathrm{m}, 4.6 \mathrm{~mm}$ I.D $\times 150 \mathrm{~mm})$ at an oven temperature of $25^{\circ} \mathrm{C}$, a mobile phase of $0.1 \%$ formic acid in water and $0.1 \%$ formic acid in methanol $(40: 60, v / v)$, and a detection wavelength of $340 \mathrm{~nm}$ were used to carry out the HPLC assay. A volume of $20 \mu \mathrm{L}$ of sample was then injected into it. Thereafter, the solutions were filtered through a $0.45 \mu \mathrm{m}$ nylon membrane prior to HPLC injection. The chromatographic analyses were conducted at a run time of $0,20,25,25.1$ and $30 \mathrm{~min}$.

\subsection{Statistical Analysis}

GraphPad Prism 7.0 for windows (GraphPad Software Inc., LaJolla, CA, USA) was used to analyse the data. One-way analysis of variance (ANOVA) followed by Tukey's post hoc test was used to analyse values with normal distribution and homogenous variance. Data are presented as mean \pm standard deviation (SD). $p$-value $<0.05$ was considered statistically significant.

\section{Conclusions}

Our study revealed that BBE showed significantly higher DPPH radical scavenging activity, $\mathrm{H}_{2} \mathrm{O}_{2}$ scavenging activity, total phenolic and flavonoid contents as well as FRAP activity, than BBW and BBH. HPLC analysis of BBE showed the presence of five phenolic acids (gallic acid, caffeic acid, trans-ferulic acid, trans 3-hydroxycinnamic acid, 2-hydroxycinnamic acid) and four flavonoids (quercetin, kaempferol, apigenin and mangiferin). Finally, the antimicrobial activity of BBE was stronger in Shigella, followed by Salmonella typhi, E. coli and Klebsilla pneumonia. Bee bread used in the present study, therefore, possesses compounds (flavonoids and phenolic acids) which can reduce oxidative stress, inflammation and apoptosis, and prevent microbial growth, thereby making it a promising therapy for some disease conditions.

Author Contributions: Conceptualization, M.M. and A.B.A.; methodology, J.B.S.; software, J.B.S.; validation, V.U.N., Z.A.O. and Z.Z.; formal analysis, J.B.S.; investigation, J.B.S., V.U.N., Z.A.O., A.B.A. and Z.Z.; writing-original draft preparation, J.B.S., V.U.N., Z.A.O., A.B.A. and Z.Z.; writingreview and editing, J.B.S., V.U.N., Z.A.O., A.B.A and Z.Z.; visualization, J.B.S., M.M. and A.B.A.B.; supervision, M.M. and A.B.A.B.; project administration, M.M., and A.B.A.; funding acquisition, M.M. and A.B.A.B. All authors have read and agreed to the published version of the manuscript.

Funding: This research was funded by the Ministry of Higher Education, Malaysia (Fundamental Research Grant Scheme: 203.PPSP.6171195).

Institutional Review Board Statement: Not applicable.

Informed Consent Statement: Not applicable.

Data Availability Statement: The datasets for this manuscript can be obtained from the corresponding author upon reasonable request. 
Acknowledgments: The authors hereby acknowledge the Ministry of Higher Education (Fundamental Research Grant Scheme: 203. PPSP.6171195), Malaysia for funding this research and Universiti Sains Malaysia, Malaysia for giving the first author the USM Graduate Assistant Scheme Award.

Conflicts of Interest: The authors declare no conflict of interest.

Sample Availability: Samples of bee bread are available from the authors.

\section{References}

1. Disayathanoowat, T.; Li, H.; Supapimon, N.; Suwannarach, N.; Lumyong, S.; Chantawannakul, P.; Guo, J. Different Dynamics of Bacterial and Fungal Communities in Hive-Stored Bee Bread and Their Possible Roles: A Case Study from Two Commercial Honey Bees in China. Microorganisms 2020, 8, 264. [CrossRef] [PubMed]

2. Nagai, T.; Nagashima, T.; Myoda, T.; Inoue, R. Preparation and Functional Properties of Extracts from Bee Bread. Mol. Nutr. Food Res. 2004, 48, 226-229. [CrossRef] [PubMed]

3. Ahmed, S.; Sulaiman, S.A.; Baig, A.A.; Ibrahim, M.; Liaqat, S.; Fatima, S.; Jabeen, S.; Shamim, N.; Othman, N.H. Honey as a Potential Natural Antioxidant Medicine: An Insight into Its Molecular Mechanisms of Action. Oxidative Med. Cell. Longev. 2018, 2018, 1-19. [CrossRef] [PubMed]

4. Janashia, I.; Choiset, Y.; Józefiak, D.; Déniel, F.; Coton, E.; Moosavi-Movahedi, A.A.; Chanishvili, N.; Haertlé, T. Beneficial Protective Role of Endogenous Lactic Acid Bacteria Against Mycotic Contamination of Honeybee Beebread. Probiotics Antimicrob. Proteins 2018, 10, 638-646. [CrossRef] [PubMed]

5. Komosinska-Vassev, K.; Olczyk, P.; Kaźmierczak, J.; Mencner, L.; Olczyk, K. Bee Pollen: Chemical Composition and Therapeutic Application. Evid. Based Complement. Altern. Med. 2015, 2015, 1-6. [CrossRef]

6. Mărgăoan, R.; Strant, M.; Varadi, A.; Topal, E.; Yücel, B.; Cornea-Cipcigan, M.; Campos, M.G.; Vodnar, D.C. Bee Collected Pollen and Bee Bread: Bioactive Constituents and Health Benefits. Antioxidants 2019, 8, 568. [CrossRef] [PubMed]

7. Paramás, A.M.G.; Bárez, J.A.G.; Marcos, C.C.; García-Villanova, R.J.; Sánchez, J.S. HPLC-Fluorimetric Method for Analysis of Amino Acids in Products of the Hive (Honey and Bee-Pollen). Food Chem. 2006, 95, 148-156. [CrossRef]

8. Andjelkovic, B.; Jevtic, G.; Markovic, J.; Mladenovic, M.; Pseva, V. Quality of Honey Bee Bread Collected in Spring. Proc. Int. Symp. Anim. Sci. 2015, 1, 450-454.

9. Stanciu, O.; Marghitas, L.A.; Dezmirean, D. Examination of Antioxidant Capacity of Beebread Extracts by Different Complementary Assays. Bull. USAMV-CN 2007, 63, 1-4.

10. Kaplan, M.; Karaoglu, Ö.; Eroglu, N.; Silici, S. Fatty Acid and Proximate Composition of Bee Bread. Food Technol. Biotechnol. 2016, 54, 497. [CrossRef]

11. Stanciu, O.; Marghitas, L.-A.; Dezmirean, D. Macro-and Oligo-Mineral Elements from Honeybee-Collected Pollenand Beebread Harvested from Transylvania (Romania). Bull. Univ. Agric. Sci. Vet. Med. Cluj-Napoca. Anim. Sci. Biotechnol. 2009, 66, 1-2.

12. Ahuja, A.; Ahuja, V. Apitherapy-A Sweet Approach to Dental Diseases-Part I: Honey. J. Adv. Dent. Res. I 2010, 1, 81-86.

13. Zerdani, I.; Abouda, Z.; Kalalou, I.; Faid, M.; Ahami, M. The Antibacterial Activity of Moroccan Bee Bread and Bee-Pollen (Fresh and Dried) against Pathogenic Bacteria. Res. J. Microbiol. 2011, 6, 376-384. [CrossRef]

14. Tichý, J.; Novak, J. Detection of Antimicrobials in Bee Products with Activity against Viridans Streptococci. J. Altern. Complement. Med. 2000, 6, 383-389. [CrossRef]

15. Bogdanov, S. Functional and Biological Properties of the Bee Products: A Review. Bee Prod. Sci. 2011, 1, 1-12.

16. Estevinho, M.L.M.F.; Rodrigues, S.S.Q.; Pereira, A.P.; Feás, X. Portuguese Bee Pollen: Palynological Study, Nutritional and Microbiological Evaluation. Int. J. Food Sci. Technol. 2011, 47, 429-435. [CrossRef]

17. Hider, R.C. Honeybee Venom: A Rich Source of Pharmacologically Active Peptides. Endeavour 1988, 12, 60-65. [CrossRef]

18. Gómez-Caravaca, A.M.; Romero, M.G.; Arraez-Roman, D.; Segura-Carretero, A.; Gutierrez, A.F. Advances in the Analysis of Phenolic Compounds in Products Derived from bees. J. Pharm. Biomed. Anal. 2006, 41, 1220-1234. [CrossRef] [PubMed]

19. Imran, M.; Salehi, B.; Sharifi-Rad, J.; Gondal, T.A.; Saeed, F.; Imran, A.; Shahbaz, M.; Fokou, P.V.T.; Arshad, M.U.; Khan, H.; et al. Kaempferol: A Key Emphasis to Its Anticancer Potential. Molecules 2019, 24, 2277. [CrossRef] [PubMed]

20. Orsolic, N. Possible Molecular Targets of Bee Venom in the Treatment of Cancer: Application and Perspectives. Forum Immunopathol. Dis. Ther. 2013, 4, 275-315. [CrossRef]

21. Othman1, Z.A.; Noordin, L.; Ghazali, W.S.W.; Omar, N.; Mohamed, M. Nutritional, Phytochemical and Antioxidant Analysis of Bee Bread from Different Regions of Malaysia. Indian J. Pharm. Sci. 2019, 81, 955-960. [CrossRef]

22. Eleazu, C.; Suleiman, J.B.; Othman, Z.A.; Zakaria, Z.; Nna, V.U.; Hussain, N.H.N.; Mohamed, M. Bee Bread Attenuates High Fat Diet Induced Renal Pathology in Obese Rats via Modulation of Oxidative stress, Downregulation of NF-kB Mediated Inflammation and Bax Signalling. Arch. Physiol. Biochem. 2020, 1-17. [CrossRef]

23. Vásquez, A.; Olofsson, T.C. The Lactic Acid Bacteria Involved in the Production of Bee Pollen and Bee Bread. J. Apic. Res. 2009, 48, 189-195. [CrossRef]

24. DeGrandi-Hoffman, G.; Eckholm, B.; Huang, M.H. A Comparison of Bee Bread made by Africanized and European Honey Bees (Apis Mellifera) and its Effects on Hemolymph Protein Titers. Apidologie 2012, 44, 52-63. [CrossRef]

25. Aylanc, V.; Falcão, S.I.; Ertosun, S.; Vilas-Boas, M. From the Hive to the Table: Nutrition Value, Digestibility and Bioavailability of the Dietary Phytochemicals Present in the Bee Pollen and Bee Bread. Trends Food Sci. Technol. 2021, 109, 464-481. [CrossRef] 
26. Akhir, R.A.M.; Abu Bakar, M.F.; Sanusi, S.B. Antioxidant and Antimicrobial Activity of Stingless Bee Bread and Propolis. Extracts 2017. [CrossRef]

27. Baltrušaitytè, V.; Venskutonis, P.R.; Čeksterytė, V. Radical Scavenging Activity of Different Floral Origin Honey and Beebread Phenolic Extracts. Food Chem. 2007, 101, 502-514. [CrossRef]

28. Isidorov, V.; Isidorova, A.; Sczczepaniak, L.; Czyżewska, U. Gas Chromatographic-Mass Spectrometric Investigation of the Chemical Composition of Beebread. Food Chem. 2009, 115, 1056-1063. [CrossRef]

29. Tavdidishvili, D.; Khutsidze, T.; Pkhakadze, M.; Vanidze, M.; Kalandia, A. Flavonoids in Georgian Bee Bread and Bee Pollen. J. Chem. Chem. Eng. 2014, 8, 676-681.

30. Sobral, F.; Calhelha, R.C.; Barros, L.; Dueñas, M.; Tomás, A.; Santos-Buelga, C.; Vilas-Boas, M.; Ferreira, I.C.F.R. Flavonoid Composition and Antitumor Activity of Bee Bread Collected in Northeast Portugal. Molecules 2017, 22, 248. [CrossRef]

31. Bakour, M.; Fernandes, Â.; Barros, L.; Sokovic, M.; Ferreira, I.C. Bee bread as a functional product: Chemical Composition and Bioactive Properties. LWT 2019, 109, 276-282. [CrossRef]

32. Urcan, A.C.; Criste, A.D.; Dezmirean, D.S.; Mărgăoan, R.; Caeiro, A.; Campos, M.G. Similarity of Data from Bee Bread with the Same Taxa Collected in India and Romania. Molecules 2018, 23, 2491. [CrossRef] [PubMed]

33. Ivanišová, E.; Kačániová, M.; Frančáková, H.; Petrová, J.; Hutková, J.; Brovarskyi, V.; Velychko, S.; Adamchuk, L.; Schubertová, Z.; Musilová, J. Bee Bread-Perspective Source of Bioactive Compounds for Future. Potravin. Slovak J. Food Sci. 2015,9 , 592-598. [CrossRef]

34. Borycka, K.; Grabek-Lejko, D.; Kasprzyk, I. Antioxidant and Antibacterial Properties of Commercial Bee Pollen Products. J. Apic. Res. 2015, 54, 491-502. [CrossRef]

35. Raaman, N. Phytochemical Techniques; New India Publishing: Delhi, India, 2006.

36. Ajayi, G.; Olagunju, J.; Ademuyiwa, O.; Martins, O. Gas Chromatography-Mass Spectrometry Analysis and Phytochemical Screening of Ethanolic Root Extract of Plumbago Zeylanica. Linn. J. Med. Plant. Res. 2011, 5, 1756-1761.

37. Ganesh, S.; Vennila, J.J. Phytochemical Analysis of Acanthus Ilicifolius and Avicennia Officinalis by GC-MS. Res. J. Phytochem. 2011, 5, 60-65. [CrossRef]

38. Oršolić, N.; Sirovina, D.; Končić, M.Z.; Lacković, G.; Gregorović, G. Effect of Croatian Propolis on Diabetic Nephropathy and Liver Toxicity in Mice. BMC Complement. Altern. Med. 2012, 12, 117. [CrossRef] [PubMed]

39. Benzie, I.F.; Strain, J. Ferric Reducing/Antioxidant Power Assay: Direct Measure of Total Antioxidant Activity of Biological Fluids and Modified Version for Simultaneous Measurement of Total Antioxidant Power and Ascorbic Acid. Concentration 1999, 299, 15-27. [CrossRef]

40. Gülçın, İ.; Oktay, M.; Kıreçcı, E.; Küfrevığlu, Ö.İ. Screening of Antioxidant and Antimicrobial Activities of Anise (Pimpinella Anisum, L.) Seed Extracts. Food Chem. 2003, 83, 371-382. [CrossRef]

41. Marigo, G. On a Fractionation Method and Estimation of the Phenolic Compounds in Plants. Analysis 1973, 2, 106-110.

42. El Hariri, B.; Sallé, G.; Andary, C. Involvement of Flavonoids in the Resistance of Two Poplar Cultivars to Mistletoe (Viscum Album L.). Protoplasma 1991, 162, 20-26. [CrossRef]

43. Ezeigbo, O.; Nwachukwu, I.; Ike-Amadi, C.; Suleiman, J. Evaluation of the Phytochemical, Proximate and Mineral Constituents of Breynia nivosa Leaf. Int. J. Biochem. Res. Rev. 2017, 20, 1-8. [CrossRef]

44. Chen, S.C.A.; O’Donnell, M.L.; Gordon, S.; Gilbert, G.L. Antifungal Susceptibility Testing using the E Test: Comparison with the Broth Macrodilution Technique. J. Antimicrob. Chemother. 1996, 37, 265-273. [CrossRef] [PubMed] 